EduLib, Vol 3, No.1 Mei 2013

\title{
HAK AKADEMISI PELAKU PLAGIARISME DIPANDANG DARI SUDUT PANDANG ETIKA LIBERAL
}

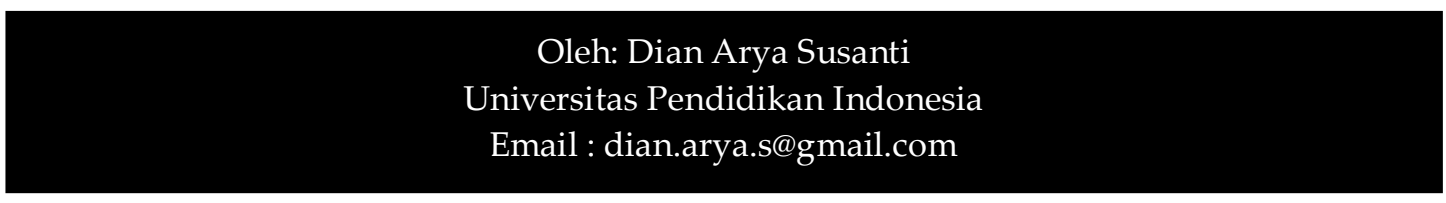

\begin{abstract}
Plagiarism is an academic sin, but still exist even by the academic community in Indonesia. Director General of Higher Education at the note that's been circulated, there are 21 state universities and seven private universities in the list of cases of plagiarism. Actors in plagiarism obviously having a big loss. Demotion, even a moratorium on the recruitment of professors for the institutions is definitely a very big loss. This paper tries to see how the actors right from an ethical standpoint of plagiarist liberalism who exalts individual freedom. By taking Nozick as a character that upholds individual liberty, however,it was found that, still, the behavior of plagiarism is an act that violates the principles of justice.
\end{abstract} Keywords: Plagiarism, Academics, Ethics Liberalism

\begin{abstract}
Abstrak
Plagiarisme adalah sebuah dosa besar dalam dunia akademik. Walaupun demikian, hal ini masih seringkali terjadi, yang bahkan dilakukan oleh para pelaku akademik itu sendiri. Direktorat Jeneral Pendidikan Tinggi menyatakan bahwa terdapat 21 perguruan tinggi negeri dan 7 perguruan tinggi swasta yang didaulat sebagai pelaku plagiarism. Pelaku plagiarisme dalam hal ini jelas besar pasak daripada tiang. Demosi sampai dengan moratorium pengangkatan profesor untuk institusi pelaku plagiarism jelas merupakan sesuatu yang sangat merugikan. Artikel ini mencoba untuk meninjau, bagaimana para pelaku plagiarism dari sudut pandang etika liberalism, yang sangat mennyanjung tinggi kebebasan individual. Dari hasil kajian, ternyata, dengan mengambil pendapat Nozick sebagai tokoh kebebasan individu sekalipun, perilaku plagiarism tetaplah sebuah tindakan yang melanggar prinsip-prinsip keadilan.
\end{abstract}

Kata Kunci: Plagiarisme, Pendidikan Tinggi, Etika Liberalisme

\section{A. PENDAHULUAN}

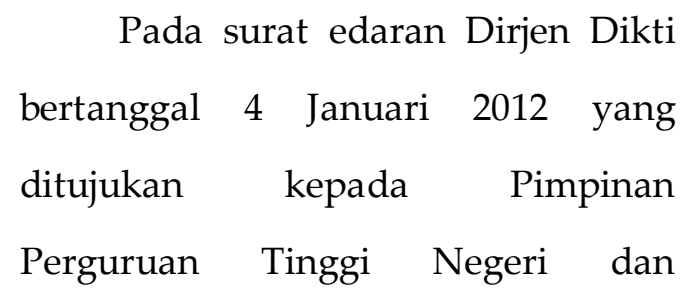

Pada surat edaran Dirjen Dikti nama-nama perguruan tinggi dan swasta yang masuk ke dalam daftar kasus pelanggaran norma akademik berupa plagiarisme. Jumlah 
Perguruan Tinggi yang termasuk dalam daftar tersebut berjumlah 21 PTN dan 7 PTS. Jumlah yang sangat banyak bila dibandingkan dengan jumlah seluruh perguruan tinggi negeri di seluruh negeri tercinta ini.

Masalah plagiarisme dalam lingkungan akademisi merupakan sesuatu yang 'horrified', sebuah 'mockery' bagi wajah pendidikan bangsa Indonesia. Akan tetapi, bila ditelusur lebih jauh, sebenarnya masalah plagiarisme ini merupakan sesuatu yang menguratakar di bumi pertiwi ini. Salah satu contoh akar budaya berbasis peniruan ini ialah kebanggaan orang-orang Bali bila kemampuan mereka dalam mengukir kayu ditiru oleh banyak orang. Makin banyak yang meniru karyanya, semakin bahagia dia. Selain itu, budaya gotong royong dan kuatnya solidaritas yang tercermin dalam kegiatan saling tolong menolong, menyuburkan budaya plagiarisme.

Bila dilihat dari sudut pandang hak intelektual, tentunya plagiarisme merupakan sebuah pelanggaran hak cipta si penulis. Hukum ini berdasarkan pada Konvensi Bern dan berlaku hampir di seluruh dunia. Kebanyakan analisis selalu mengedepankan hak penulis yang dilanggar, akan tetapi, bagaimana dengan hak mereka yang melakukan plagiasi? Karena pada banyak kasus sebenarnya para akademisi cukup paham mengenai aturan-aturan plagiarisme ini, akan tetapi 'terpeleset' dan divonis melakukan plagiasi secara sengaja. Vonis ini jelas menjadi sebuah kerugian bagi mereka yang bersangkutan, baik secara moril maupun materil.

Berdasarkan fenomena diatas, maka makalah ini disusun untuk menganalisis hak-hak 'plagiator' dari sisi etika liberalisme.

\section{B. METODE}

1. Metode Pengumpulan Data Makalah ini disusun dengan menggunakan metode kualitatif berupa studi literatur, dimana data-data 
EduLib, Vol 3, No. 1 Mei 2013

baik berupa angka maupun

fakta, yang dikumpulkan dari

literatur-literatur yang

berkaitan dengan masalah-

masalah yang diajukan, serta

pernyataan sebagai hasil

wawancara maupun hasil

pengamatan lapangan.

Metode Analisis Data

Tujuan dari makalah ini

pada intinya adalah mengkaji

sebuah fenomena yang hadir

dan nyata terjadi dalam

keseharian hidup kita sebagai

sebuah bangsa. Maka analisis

yang perlu dilakukan bila data

sudah terkumpul adalah

mengorganisasikan data,

menguji keabsahan data, lalu

mencoba mengaitkannya

dengan teori-teori yang tepat

dan memang berkaitan dengan

fenomena tersebut.

\section{PEMBAHASAN}

1. Plagiarisme

$\begin{array}{ll}\text { Secara } & \text { definitif, } \\ \text { plagiarisme bisa diartikan } \\ \text { sebagai sebuah tindakan }\end{array}$

melakukan plagiasi.

Universityof New South Wales

memberikan definisi

plagiarisme untuk

mahasiswanya sebagai

"using the words or ideas of

others and presenting them as

your own. Lebih jauh lagi,

plagiarism is a type of

intellectual theft. It can take

many forms, from deliberate

cheating to accidentally

copying from a source without

acknowledgement"

Flinders University juga

memberikan definisi untuk plagiarisme sebagai the use of another's ideas or words as if they were one's own.

Bila ditarik dari dua definisi diatas, bisa disimpulkan bahwa kegiatan plagiarisme adalah bila seseorang menggunakan ideide atau kata-kata milik orang lain dan menggunakannya serta mengakuinya sebagai miliknya pribadi. Kata yang 
seringkali diasosiasikan

dengan plagiarisme adalah

'penjiplakan'. Kedua istilah ini

memiliki asosiasi negatif bila

dikenai kepada suatu subjek

tertentu, baik dikaitkan

dengan hal yang abstrak

seperti masalah etika, maupun

dalam hal yang sifatnya fisik, misalnya seperti kasus-kasus

hukum yang pernah terjadi.

Kegiatan atau aktivitas

plagiarisme ini menurut

Barnbaum

(Valdosta

University) terbagi menjadi

lima jenis, yaitu;

a. Copy \& Paste adalah Plagiarisme. Setiap kali kita akan

mengangkat/mengutip

sebuah anak kalimat atau paragraf utuh dari sumber, maka kita harus menggunakan tanda kutipan dan memberikan referensi sumber. b. Mengganti dengan bahasa sendiri adalah

Plagiarisme. Jika kita mengambil sebuah kalimat dari sumber dan melakukan perubahan beberapa kata atas kalimat itu, hal ini masih dikatakan plagiarisme. Jadi jika kita ingin mengutip sebuah kalimat, maka kita harus meletakkannya dalam tanda kutip dan mengutip penulis dan dari mana artikel itu didapatkan. Tapi kebanyakan orang mengutip artikel, tanpa menyertakan sumber utama artikel. Mengutip harus dilakukan apabila ada hubungan manfaat antara kutipan kata ini dengan kalimat yang kita tulis, terutama manfaat ini terasa ketika dibaca berulang-ulang. Dalam 
EduLib, Vol 3, No. 1 Mei 2013

banyak kasus, untuk

menghindari pengutipan

semacam ini, lebih baik

kita mengutip langsung

dari sumber-sumber asli.

Hal ini adalah pilihan

yang lebih baik.

c. Mengikuti gaya penalaran kutipan

adalah

Plagiarisme. Ketika kita

mengikuti sebuah sumber

kalimat demi kalimat atau

paragraf demi paragraf,

itu adalah tindakan

plagiarisme, meskipun tak

satu pun dari kalimat kita

yang persis sama seperti

yang ada di artikel atau

sumber, bahkan urutan

yang berneda juga. Jadi

dengan demikian, dalam

kasus ini kita sudah

menyalin gaya penalaran

penulis.

d. Penulisan Metafora adalah

Plagiarisme. Penulisan

metafora biasanya

digunakan baik untuk membuat lebih jelas ide

atau memberikan pembaca

sebuah analogi yang

menyentuh indera atau

emosi lebih baik, dengan

adanya gambaran yang

jelas dari objek atau proses

Metafora itu sendiri.

Kemudian juga mengikuti

bagian penting dari gaya kreatif si penulis tersebut. Jika kita tidak bisa membuat kalimat sebagus metafora si penulis (sumber), sebaiknya kita datang dengan penulisan metafora si penulis untuk dapat menggambarkan ide penting yang ada pada tulisan, oleh karena itu apabila ingin berlaku demikian, kita harus mencantumkan secara penuh kredit penulis untuk sumber itu.

e. Mengikuti Ide penulis adalah Plagiarisme. Jika kita menulis sebuah artikel 
dengan mengikuti sumber

dalam mengungkapkan ide kreatif atau menyarankan solusi untuk suatu masalah pembaca, maka ide atau solusi harus jelas dikaitkan dengan penulis sebenarnya. Banyak mahasiswa yang tampaknya kesulitan untuk membedakan mana yang kalimat gagasan (ide) dan / atau solusi dari informasi yang disajikan penulis. Gagasan informasi umum adalah setiap ide atau solusi mengenai sesuatu yang orang di lapangan menerima sebagai pengetahuan umum dan meberikan makna tersendiri bagi mereka. Namun, ide baru tentang bagaimana untuk mencari solusi dari informasi itu perlu dikaitkan dengan penulis sebenarnya sebagai literatur.

Random House Compact Unabridged Dictionary (1995) menyatakan bahwa kegiatan plagiarisme bisa disengaja (intentionally) dan bisa saja tidak disengaja (unintentionally). Maksudnya dengan tidak disengaja adalah bila seseorang memasukkan kata-kata, ide-ide atau pemikiran seseorang pada tulisannya sendiri, akan tetapi lupa mencantumkan sumbersumber pustaka atau tidak mengetahui bagaimana cara untuk mensitasi atau mengutip hasil karya orang lain ke dalam tulisannya.

Dengan melihat fenomena diatas, akan sangat mudah seseorang terpeleset dan masuk ke dalam 'vonis' plagiarisme. Apalagi di Indonesia, pengetahuan mengenai plagiarisme belum 
EduLib, Vol 3, No.1 Mei 2013

termasyarakatkan secara

merata, baik di bidang

akademik maupun jurnalisme.

Apalagi dengan semakin

'canggih'nya teknologi

komunikasi informasi, dimana

internet membuat karya cipta

dan karsa seseorang bisa

didapatkan dalam bentuk

digital, dimana dengan

demikian akan sangat lebih

mudah dijiplak.

Pada kasus-kasus yang telah terjadi, baik di luar negeri maupun di dalam negeri, tidak sekali dua kali, seringkali seseorang terpeleset kedalam kasus plagiarisme karena tidak sengaja. Seorang Helen Keller, tokoh pendidikan difabel, pernah masuk kedalam kasus plagiarisme karena beliau secara tidak sengaja mengutip sebuah novel dan memasukkannya ke dalam novel miliknya tanpa menuliskan sumber aslinya. Beliau berargumen bahwa mungkin beliau tanpa sengaja pernah membaca (dibacakan, karena beliau difabel) novel yang dikutipnya pada suatu saat dimasa kecilnya dan terlupa, akan tetapi esensi kisah tersebut menginspirasinya sehingga membuat Helen Keller ingin menuliskannya. Hal-hal seperti ini sangat mungkin terjadi, dan bisa saja menipa siapa saja. Tidak hanya mahasiswa, pelajar, dosen, jurnalis, penulis maupun guru besar pun sangat mungkin terpeleset kedalam kasus ini.

2. Plagiarisme di Kalangan Akademisi

Kasus plagiarisme yang terjadi pada kalangan akademisi di Indonesia, pun sebenarnya termasuk ke dalam golongan 'tidak dengan sengaja' dilakukan. Pada kasus dosen UNS yang menjiplak sebuah buku dan diakui sebagai bukunya sendiri 
merupakan sebuah kesalahan karena kurangnya kontrol dari sang dosen sebagai penulis utama terhadap ghost writernya. Akibatnya adalah penurunan pangkat bagi sang penulis utama, karena dianggap lalai. Hukuman ini cukup ringan karena Senat Akademik UNS menganggap kejadian ini tidak disengaja. Bila kejadiannya berbeda, sudah pasti sang dosen akan langsung kehilangan pekerjaannya.

Entah apa yang terjadi dengan tiga dosen UPI yang melakukan plagiarisme, apakah mereka melakukannya dengan sengaja atau tidak dengan sengaja, tidak ada media yang benar-benar tahu apa yang terjadi karena pejabat universitas menutup rapatrapat informasi mengenainya. Yang pasti adalah pengajuan guru besar ketiga dosen tersebut dibatalkan dan UPI mendapat sanksi moratorium pengajuan guru besar bagi seluruh dosen selama satu tahun. Sungguh sebuah kerugian yang sangat besar, yang tidak hanya menimpa pelaku plagiarisme yang terkena sanksi, bahkan satu institusi turut terkena getahnya.

Dan seperti yang telah disebutkan pada pendahuluan bahwa dalam Surat Edaran Dirjen DIKTI Dinas Pendidikan Indonesia dinyatakan bahwa terdapat 21 PTN dan 7 PTS yang terlibat kedalam kasus plagiarisme. PTN yang disebutkan dalam surat edaran tersebut adalah Universitas Hasanuddin, Universitas Andalas, Universitas Indonesia, Universitas Brawijaya, Universitas Lampung, Universitas Jambi, Universitas 
EduLib, Vol 3, No.1 Mei 2013

Padjadjaran, Universitas

Mataram, Universitas Sebelas

Maret Surakarta, Universitas

Sam Ratulangi, Universitas

Sultan Ageng Tirtayasa,

Universitas

Udayana,

Universitas Sumatera Utara,

Universitas Pattimura,

Universitas Negeri Gorontalo,

Universitas Negeri Medan,

Universitas Negeri Makassar,

Universitas Pendidikan

Indonesia, Universitas Negeri

Surabaya, Institut Teknologi

Sepuluh Nopember, dan

Institut Pemerintahan Dalam

Negeri.

Subekti dalam blognya

menuliskan kajiannya

mengenai beberapa penyebab

maraknya plagiarisme di

Indonesia. Penyebab-penyebab

tersebut yaitu;

a. Minimnya perhatian kampus untuk mengurusi isu plagiarisme membuat mahasiswa dan dosen tanpa sadar melakukan plagiarisme. Hal ini sebaiknya menjadi koreksi kampus ketika akan menjatuhkan saksi plagiarisme. Silahkan Anda mencari tahu di kampus Anda apakah ada peraturan tertulis tentang plagiarisme berserta dengan sanksi-sanksi. Saya

mencoba searching ke beberapa website Perguruan Tinggi di Indonesia, hampir tidak menemukan informasi yang jelas dan akurat dengan plagiarisme dan sanksi-sanksinya sehingga bisa diakses dan dipahami oleh civitas akademika kampus.

b. Buruknya mental sebagian akademisi Indonesia menjadikan plagiarisme semakin bertumbuh subur. Tidak sedikit ditemukan kasus 


\begin{tabular}{|c|c|}
\hline mahasiswa dan tenaga & sedikit karya akademik \\
\hline akademik & dikonsumsi \\
\hline melakukan tindakan tidak & kalangan \\
\hline seperti copy & sehingga sebuah karya \\
\hline paste karya orang lain & hasil plagiat tidak dengan \\
\hline atau hanya sekedar & mudah dan cepat bisa \\
\hline mengganti sampul dan & terdeteksi. \\
\hline diberi namanya. & karya-karya mahasiswa \\
\hline Kebiasaan malas dan & dan dosen diunduh online \\
\hline hanya mau jalan singkat & beberapa bagian \\
\hline menghinggapi sebagian & (misalnya judul dan \\
\hline kalangan civitas & abstraknya) maka dengan \\
\hline akademika. & mudah bisa diakses orang \\
\hline kebiasaan ini harus & luar. Dengan bantuan \\
\hline ditumpas sejak awal & pencari \\
\hline secara perlahan dan & misalnya GOOGLE karya- \\
\hline bijaksana. Peraturan yang & karya serupa bisa dengan \\
\hline ketat seputar kegiatan dan & mudah ditampilkan. Jadi, \\
\hline karya akademik di & menjadikan sebagian \\
\hline kampus bisa membuat & karya mahasiswa dan \\
\hline mereka yang akan & dosen online secara tidak \\
\hline melanggar berpikir dua & langsung \\
\hline kali. & kalangan \\
\hline Buruknya akses informasi & akademika kampus untuk \\
\hline menjadikan plagiarisme & hati-hati dalam membuat \\
\hline tertutupi dan terlindungi. & sebuah karya karena ada \\
\hline pengamatan saya, tidak & \\
\hline
\end{tabular}


EduLib, Vol 3, No. 1 Mei 2013

banyak mata yang siap

melihat.

d. Kesibukan dosen yang berlebih menjadikan mereka tidak memiliki waktu untuk meneliti karya mahasiswanya. Walhasil semua karya yang diberikan mahasiswa diamini saja tanpa dilihat lebih jauh kandungan plagiarisme. Dosen atau akademisi dengan mental mengejar setoran dan lompat sana-sini untuk mencari tambahan jam mengajar tanpa menghiraukan kualitas pembelajaran dan mengejar proyek menjadikan plagiarisme tidak tersentuh secara maksimal. Argumen tersebut merupakan kritik yang keras terhadap dunia pendidikan di Indonesia.

Masalah penjiplakan sudah mulai menjadi perhatian dunia sejak Konvensi Bern tahun $1886 \quad$ tentang perlindungan karya sastra dan seni yang diikuti dengan Konvensi Hak Cipta Universal pada tahun 1955. Di Indonesia, perlindungan hak cipta sudah mulai diberlakukan jauh sebelum proklamasi dikumandangkan, berupa Auteurswet tahun 1912. Peraturan ini dianggap tidak berlaku lagi mulai dengan berlakunya Undang-undang Hak Cipta pada tahun 1982. Peraturan ini terus mengalami perubahan seiring dengan perkembangan objek peraturannya. Peraturan ini mengalami perubahan pada tahun 1987, lalu pada tahun 1997 dan terakhir tahun 2002. Terlepas dari latar belakang kemunculan Undang-undang hak cipta sendiri, yang jelas kemunculannya tidak memberi arti banyak terhadap 


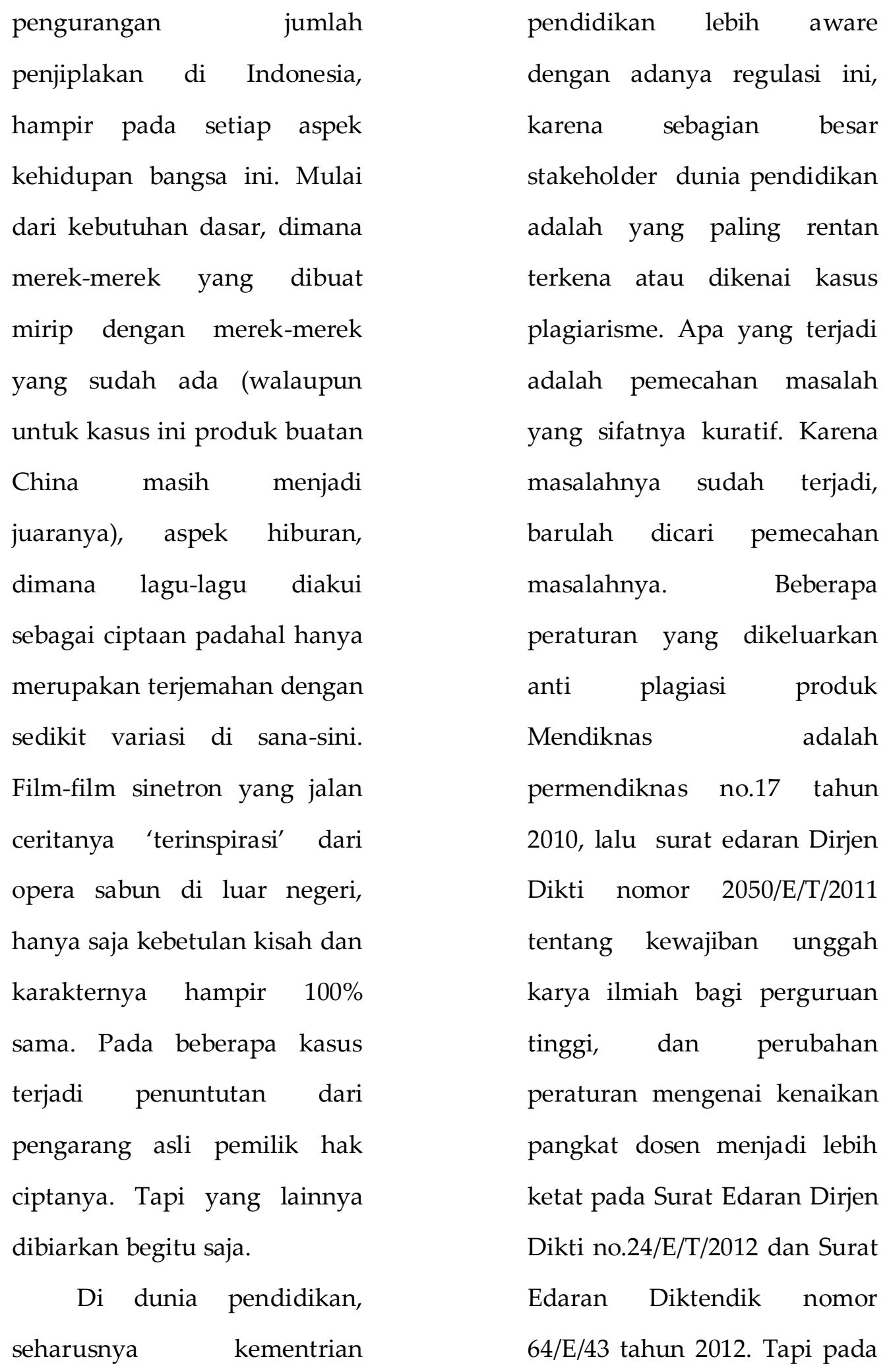


EduLib, Vol 3, No.1 Mei 2013

saat itu terjadi sudah ada banyak korban yang dirugikan.

Pada kasus tertentu, di sebuah dunia yang paralel dengan dunia pendidikan, ada yang sudah terlebih dahulu aware terhadap masalah ini. Perpustakaan di Indonesia sudah memperhatikan undang-undang hak cipta dengan segala

pengembangannya,

kemungkinan besar karena layanan yang diberikan berkaitan langsung dengan hak cipta orang atau kelompok tertentu. Selain itu, fungsinya sebagai lembaga pengelola dan penyebarluas pengetahuan tentunya menjadi sangat rentan dengan terganggunya hak pemilik pengetahuan tersebut. Walaupun memang pada UUHC tahun 2002 disebutkan bahwa penggandaan suatu karya ciptaan diperbolehkan bila diperuntukkan bagi

kepentingan pendidikan dan tidak untuk dikomersilkan. Akan tetapi penggandaan dan penjiplakan memang dua kasus yang berbeda.

3. Hak Pelaku Plagiarisme dari Sudut Pandang Etika Liberal

Dalam paham Liberalisme, keberadaan individu dan kebebasannya adalah hal yang sangat diagungkan. Setiap individu berhak untuk berfikir dan melakukan apa yang difikirkannya. Akan tetapi kebebasan ini tidak sepenuhnya atau tidak mutlak, karena kebebasan ini harus bisa dipertanggungjawabkan. Bila dilihat dari sisi ini, pelaku plagiarisme memiliki hak untuk melakukan penjiplakan karya orang lain.

Menurut

Grotius, perolehan hak milik dalam suatu masyarakat negatif dalam keadaan alamiah, 
dimana hak milik bersama terbuka untuk diambil dan dijadikan hak milik pribadi. Nozick mendasari teori kebebasan dan kepemilikan pribadinya dengan teori ini. Nozick berpendapat bahwa "bagaimana seseorang dapat bertindak bebas jika tindakannya ditentukan secara kausal oleh faktor-faktor yang sudah ada sebelum ia lahir, dan karena itu berada di luar kendalinya?" .

Bila kita merujuk pada teori ini, pengetahuan yang bertumpuk-tumpuk di perpustakaan, pengetahuan yang berjejalan di dunia maya, semua pengetahuan itu berada di ruang publik dan sangat terbuka untuk siapa saja yang membutuhkannya. Akademisi pelaku plagiarisme pun bisa menggunakan semua pengetahuan tersebut untuk menjadi miliknya. Tetapi apakah adil bagi pemilik hak cipta yang telah bersusah payah membuat karyanya lalu diambil begitu saja oleh orang lain dan diaku sebagai miliknya?

Dalam hal ini Nozick membagi konsep keadilan pemilikan menjadi tiga bagian, yaitu;

a. Original acquisition of holding (prinsip pemilikan awal)

b. Principle of justice in transfer (prinsip keadilan pengalihan)

c. Principle of rectification of injustice in holdings (prinsip menghilangkan ketidakadilan pemilikan).

Dengan tiga prinsip ini maka kebebasan seseorang dalam mengakui hak kepemilikannya menjadi terbatas. Seseorang tidak bisa mengakui bahwa ia memiliki sesuatu bila sesuatu itu sudah 
EduLib, Vol 3, No. 1 Mei 2013

ada yang memiliki, atau bila

dalam proses pengalihan

kepemilikan terdapat

ketidakadilan dalam hal

kompensasi, dan atau bila

ternyata terjadi sebuah

ketidakadilan bagi pemilik

awal. Dari sini jelas bahwa

sebenarnya pengutipan adalah

jalan terbaik dalam

menciptakan prinsip-prinsip

keadilan dalam penulisan karya ilmiah.

\section{PENUTUP}

Seperti yang dituliskan oleh Besuki sebelumnya bahwa masyarakat akademik di Indonesia belum terlalu faham apa itu plagiarisme, sehingga menjadi sangat mudah untuk terpeleset ke dalam kasus plagiarisme. Beberapa solusi yang mungkin bisa dilaksanakan oleh masyarakat akademik untuk mencegah baik mahasiswa maupun dosen tiba-tiba terjebak dalam situasi yang tidak menyenangkan adalah dengan memberikan sosialisasi intensif dan regulasi yang ketat mengnai batasan-batasan plagiarisme.

Dengan dibantu oleh peranti lunak yang tepat tentunya hal ini sangat mungkin untuk dilakukan.

\section{E. DAFTAR PUSTAKA}

Damian, Eddy.(1999).Hukum Hak Cipta menurut Beberapa Konvensi Internasional, Undang-undang Hak Cipta 1997 dan Perlindungannya terhadap Buku serta Perjanjian Penerbitannya.

Bandung:Alumni

Shapiro, Ian.(2006).Evolusi Hak dalam

Teori Liberal. Jakarta: Yayasan

Obor Indonesia

[s.n.].2012. 20 PTN Diduga Lakukan Pelanggaran Akademik. http://www.pikiran-rakyat.com node/179134

Subekti, Nanang Bagus. (2012). Mengapa Plagiarisme Marak di Indonesia.

http://www.Blogger.com

Subekti,Nanang Bagus. (2012).

Maraknya Plagiarisme di

Indonesia.

http://www.Blogger.com 